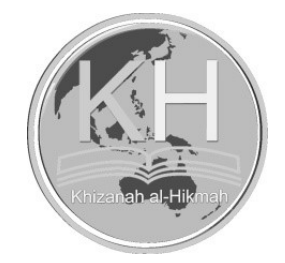

\title{
ACADEMIC LIBRARIES PROMOTION THROUGH SOCIAL MEDIA: A SYSTEMATIC LITERATURE REVIEW
}

\author{
Nur Sanny Rahmawati* \& Rahmi* \\ *Universitas Indonesia \\ Email: nsannyrahmawati@gmail.com,rahmi.ami@ui.ac.id \\ (Submitted: 10-03-2021, Revised: 25-11-2021, Accepted: 06-12-2021) \\ DOI: $10.24252 /$ v9i2a8
}

\begin{abstract}
ABSTRAK: Promosi perpustakaan melalui media sosial merupakan bagian yang tidak terpisahkan dari layanan perpustakaan, khususnya perpustakaan perguruan tinggi. Media sosial dapat menginformasikan pengguna tentang sumber daya dan layanan perpustakaan serta memberikan kesan kepada pustakawan tentang pandangan dan kebutuhan pengguna. Penelitian ini bertujuan untuk mengetahui pemanfaatan media sosial dalam mempromosikan perpustakaan perguruan tinggi di Indonesia. Penelitian ini menggunakan pendekatan kualitatif, khususnya tinjauan pustaka sistematis, dan mencakup perincian tentang mengidentifikasi pertanyaan penelitian, proses pencarian literatur, sintesis data dan hasil pencarian. Berdasarkan karya ilmiah yang diidentifikasi dan ditinjau, sebagian besar penelitian dipublikasikan pada tahun 2019. Media sosial yang paling sering digunakan untuk promosi perpustakaan adalah Facebook dan Instagram. Perpustakaan perguruan tinggi yang berlokasi di Yogyakarta paling banyak melakukan promosi media sosial. Kendala dalam mempromosikan perpustakaan melalui media sosial di Indonesia terutama karena faktor internal perpustakaan
\end{abstract}

Kata kunci: perpustakaan perguruan tinggi, media sosial, tinjauan pustaka sistematis.

\begin{abstract}
Library promotion through social media is an integral part of library services, especially for academic libraries. Social media can inform the end-users of what library's resources and services and give librarians an impression of users' views and needs. This study aimed to determine the use of social media to promote academic libraries in Indonesia. This research used a qualitative approach, specifically a systematic literature review, and includes details about identifying the research questions, the literature search process, data synthesis and search results. Based on the scientific papers identified and reviewed, the majority of research was published in 2019. The most frequent social media platforms for library promotions were Facebook and Instagram. Academic libraries located in Yogyakarta carried out the most social media promotions. Obstacles to promoting libraries through social media in Indonesia were primarily due to internal factors of libraries.
\end{abstract}

Keywords: Academic libraries; library promotion; social media

\section{INTRODUCTION}

The academic library is the heart of the university and contributes to science development in the academic community connected to a teaching and learning institution (Allen and Taylor, 2017). The Library Law in Indonesia (2007; Article 24, paragraph 3) states that academic libraries develop library services based on information and communication technology. According to the Indonesian National Work Competency Standards 2019 (Indonesia, 2019) for the Library Sector, one of the librarian's competencies in information and communication technology is accessing social media. This competency can help promote academic libraries, both in the conditions before and during the 
pandemic. Further, academic librarians must also distribute information about library services by utilizing technology, such as through social media.

Social media is a tool academic libraries can use for marketing or promotion. Social media is considered to provide an impression of users' views and desires (Collins and Quan-Haase, 2014). The use of social media can be regarded as an integral part of the academic library service. Furthermore, Suharso and Pramesti (2020) stated that promotion is a determining factor for marketing success. Library promotion leads to the exchange of information between organizations and consumers about libraries' products or services to raise awareness so that consumers can take advantage of libraries' offerings (Qalyubi, 2007). If people learn of and take advantage of a particular product or service, the promotion can be regarded as successful. To ensure this success, academic libraries must also be able to adapt to technological developments. Therefore, social media is an appropriate tool to successfully promote academic libraries. The younger generation can easily access social media, enabling libraries to market their services and create interactions between libraries and visitors or users (Collins and Quan-Haase, 2014).

In general, a large quantity of research addresses library promotion. However, less research examines academic library promotion with social media. This study uses a systematic literature review approach to synthesize information based on research results related to certain phenomena; in this case, the promotion of academic libraries through social media. This systematic literature review research can be used as a basis for further research or publications, especially research that includes library promotion through social media.

This research consists of seven parts, including the introduction. The second part discusses the previous findings. The third part discusses the literature review, including the definition of library promotion, the differences between academic libraries and other types of libraries, promotion of academic libraries in Indonesia, and promotion techniques. The fourth section discusses research methods, including preparing research questions, search strategies, search terms, literature sources, and inclusion and exclusion criteria. The fifth and sixth sections present the results and answers to research questions, including data triangulation, implications, and study limitations. The final section concludes the research as a whole.

Moreover, according to the description above, it is necessary to study the promotion of academic libraries, especially through social media. This is because social media allows librarians to promote various activities and services of academic libraries properly. In addition, social media can also be a medium between librarians and users to communicate, especially during the pandemic Covid-19 situation.

Furthermore, the problem in this research is how is the trend of research about the promotion of academic libraries through social media. The novelty in this research is identification related to research on the promotion of academic libraries through social media with a systematic literature review method. The purpose of this study is to find out the research trends regarding the promotion of academic libraries through social media in Indonesia. The results of this study are to increase awareness of research about the promotion of academic libraries through social media. In addition, the results of this study are expected to contribute to research on the promotion of academic libraries through social media so that academic library promotion activities can be carried out more effectively in the future.

\section{PREVIOUS FINDINGS}

Several studies have investigated the promotion of academic libraries through social media. Mardiastuti, Suciati, and Wiyarsih (2019) focused on implementing social or viral media in marketing Gadjah Mada University Library products and services, as well as responses from librarians. Suharso and Pramesti's research (2020) investigated interactions between librarians at Airlangga University and users on Instagram. Furthermore, Islamy and Laksmiwati (2020) examined using Facebook to introduce services and provide information from librarians at the Institut Seni Indonesia Surakarta to visitors. 
While some previous research has focused on the promotion of academic libraries through social media, much of this research used either literature study methods or case studies. However, not many studies have used a systematic literature review to examine library promotion through social media. Therefore, research using this method is necessary.

\section{LITERATURE REVIEW}

Promotion in the library context informs library users about useful services (Wiji, 2018). Darmono (2007) states that promotion is a persuasive communicative marketing mechanism that utilizes public relations techniques. The promotion itself must communicate information about the library's facilities and all forms of activities and services, including values, that exist in the library.

According to Indonesia's laws (2007), libraries are institutions that professionally manage collections of written works, printed works, and recorded works using a standard system to meet users' needs of education, research, preservation, information, and recreation. The academic library is a library under the auspices of the university. Apart from being under the auspices of an academic institution, academic libraries differ from other libraries in their objectives, which are in line with learning and teaching in an academic institution (Allen and Taylor, 2017). At first glance, a university library may appear similar to a school library, which supports teaching and learning. However, school libraries focus on developing collections to support teaching and learning activities ranging from kindergarten (Taman Kanak-Kanak) to high school (Allen and Taylor, 2017). Academic libraries focus on developing collections to support higher education and research, such as at a college or university.

As information and communication technology develop, people's information accessing habits are affected. The public prefers to find information using social media and the internet. Data from a Central Statistics Agency (2019) survey from 2015 to 2019 showed a consecutive increase in the percentage of internet users, from $21.98 \%$ in 2015 to $25.37 \%$ (2016), 32.34\% (2017), 39.90\% (2018), and $47.69 \%$ by 2019 (Badan Pusat Statistik, 2020). Furthermore, this increase was dominated by the 15-24 year age group, an age range that includes university students' average age. Of this age range, $83.58 \%$ used the internet in 2019. Based on the results of the Indonesian Internet Service Provider Association (Asosiasi Penyelenggara Jasa Internet Indonesia or APJII) survey in November 2020 (Jakarta Globe, 2020), as many as 197 million people, or 74\% of Indonesia's population, were internet users. The survey showed that the majority of respondents used the internet for more than eight hours a day to access social media. Thus, libraries, especially academic libraries, must adapt to these changes.

Academic libraries, both in Indonesia and abroad, have carried out promotions. These promotions were often conventional; for example, several academic libraries in Pekanbaru City, Riau, conducted direct user education and seminars, while the Abdurrab Library carried out exhibitions to promote the library (Sudiar et al., 2017). The conventional practice of promoting academic libraries abroad was the word of mouth methods, such as providing workshops, seminars, or public lectures held in libraries or computer laboratories (Patil and Pradhan, 2014)

Academic libraries also implement technology-based promotions, one method of which uses social media. In the academic library at the University of Southern Indiana, librarians promoted collections through social media every Tuesday using the hashtag \#booksyoudidntknowwehad to present a collection that might attract campus academics (Clark et al., 2014) As for the trend of academic promotion practices, especially in Indonesia, social media is often used to link the "messages" that academic library managers want to convey to visitors or users. For example, the Padjadjaran University Library attracted participants or visitors by adapting public relations and publicity techniques to market the library's electronic journal collections through WhatsApp, Instagram, and YouTube platforms (Wulandari et al., 2020). Thus, the ability to manage or master social media is a must for librarians, especially in a pandemic like now, which limits physical and social interaction between visitors and librarians, and library managers. 


\section{RESEARCH METHODOLOGY}

\section{Systematic literature review}

This study uses a systematic review method with a qualitative approach. Systematic review research is a comprehensive review of literature that differs from a traditional literature review. To minimize bias, it synthesizes information identified systematically (Hanley and Cutts, 2013). The systematic literature review is a research method for identifying, evaluating, and interpreting all relevant research results related to certain research questions, topics, or phenomena of concern (Kitchenham, 2004). Torres-Carrion et al. (2018) explained that the stages in the preparation of research using this method are planning (identification of research questions and limitations), conducting (tracing and identifying references that are following the research, data extraction, and synthesis), and reporting (translating results into articles).

\section{Development of Research Questions}

This research was conducted from December 2020 to February 2021. In identifying research questions and limitations, researchers used the PICOC (Population, Intervention, Comparison, Outcomes, and Context) approach from Petticrew and Roberts (2006). The components used to determine the research questions are shown in Table 1.

Table 1. Scope of Research Questions Determined using PICOC Method

\begin{tabular}{|c|c|}
\hline Criteria & Scope \\
\hline Population & Promotion of academic libraries through social media \\
\hline Intervention & $\begin{array}{l}\text { Limitations on the model, implementation, and challenges } \\
\text { of academic library promotion through social media in } \\
\text { Indonesia }\end{array}$ \\
\hline Comparison & Not found \\
\hline Outcomes & $\begin{array}{l}\text { Implementation of library promotion, social media used for } \\
\text { library promotion, the use of social media as a means of } \\
\text { promoting academic libraries in Indonesia }\end{array}$ \\
\hline Context & $\begin{array}{l}\text { A review of the results identifying academic library } \\
\text { promotion searches through social media }\end{array}$ \\
\hline
\end{tabular}

Referring to Table 1, the following research questions were determined.

RQ 1: How much research has been done on promoting academic libraries through social media in Indonesia?

RQ 2: How was social media used as a means of promoting academic libraries in Indonesia?

RQ 3: What were the obstacles to promoting academic libraries through social media in Indonesia?

\section{Search Strategy}

This study used the PRISMA (Preferred Reporting Items for Systematic Reviews and MetaAnalyses) approach. PRISMA shows a data search strategy through the search terms used, data sources, inclusion and exclusion criteria, and explanation of data search results (Handayani, 2017). However, this study did not include a section about the assessment of the quality of search results.

\section{Search Terms}

Three databases were searched: Google Scholar, Garuda RistekBRIN, and the Directory of Open Access Journals. Search terms were developed for each database. The study's search terms used the Boolean operator search methods "AND" and "OR" on Google Scholar. Table 2 shows the criteria for the search terms used in the study on Google Scholar. 
Table 2. Search Terms Used to Search Google Scholar

\begin{tabular}{cl}
\hline Criteria & \multicolumn{1}{c}{ Synonym Integration } \\
\hline Population & ("promosi perpustakaan") AND ("perguruan tinggi") AND \\
& ("media sosial") AND "kendala" OR ("tantangan") \\
Intervention & "promosi perpustakaan" AND "perguruan tinggi" AND \\
Method & ("media sosial" AND "kendala" \\
& ("memosi perpustakaan") AND ("perguruan tinggi") AND \\
&
\end{tabular}

Table 2 represents the steps used in searching Google Scholar. The applied Boolean search method is "AND". The use of "AND" is intended so that the documents found contain a combination of terms in Bahasa Indonesia, including the promotion of libraries (promosi perpustakaan), universities (perguruan tinggi), social media (media sosial), utilisation (kendala), and constraints (tantangan). The period searched on Google Scholar was 2015 to 2020.

Table 3 represents the steps used on Garuda RistekBRIN. The search method applied is a simple search without the use of Boolean Operators. When the researcher applied Boolean Operator search method, documents could not be found. The period searched via Garuda RistekBRIN was 2015 to 2020.

Table 3. Search on Garuda RistekBRIN

\begin{tabular}{cl}
\hline Criteria & \multicolumn{1}{c}{ Synonym Integration } \\
\hline Population & The use of social media for library promotion \\
Intervention & $\begin{array}{l}\text { The use of social media for library promotion, challenges, } \\
\text { and obstacles } \\
\text { Method }\end{array}$ \\
Social media for library promotion
\end{tabular}

Table 4 depicts the steps used in searching the Directory of Open Access Journals (DOAJ). The search method applied is the same as in Table 3 (Garuda RistekBRIN), a simple search without using Boolean Operators. The reason is similar, namely that when the researcher applied the Boolean Operator search method, documents could not be found. The period of the search on DOAJ was from 2015 to 2020 .

Table 4. Search on Directory of Open Access Journal

\begin{tabular}{cl}
\hline Criteria & \multicolumn{1}{c}{ Synonym Integration } \\
\hline Population & The use of social media for library promotion \\
Intervention & The use of social media for library promotion, challenges \\
& and obstacles \\
Method & Social media for library promotion \\
\hline
\end{tabular}

\section{Literature Sources}

This study's search terms were formulated over three days, from 26-28 December 2020. The databases Google Scholar, Garuda RistekBRIN, and DOAJ were used. The DOAJ portal was chosen because it was open access and had a broad coverage of library promotion through social media in Indonesia. The research was limited to publications from the period 2015-2020 or the last six years from the time this research was conducted. The time limit was based on internet user data found by a Central Statistics Agency survey conducted from 2015-2019 (Badan Pusat Statistik, 2019). 


\section{Inclusion and Exclusion Criteria}

Inclusion and exclusion criteria are used to identify appropriate scientific work to answer the specified research questions (Handayani, 2017). Researchers determined inclusion and exclusion criteria over two days, namely 28-29 December 2020. The inclusion and exclusion criteria used in this study are shown in Table 5.

Table 5. Inclusion and Exclusion Criteria

\begin{tabular}{ll}
\hline \multicolumn{1}{c}{ Inclusion } & \multicolumn{1}{c}{ Exclusion } \\
\hline $\begin{array}{l}\text { All scientific papers published in Bahasa Indonesia } \\
\text { (Indonesian language) }\end{array}$ & $\begin{array}{l}\text { Scientific work published in a language } \\
\text { other than Indonesian }\end{array}$ \\
$\begin{array}{l}\text { All scientific papers published in the last six years, } \\
\text { from } 2015 \text { to } 2020\end{array}$ & $\begin{array}{l}\text { Scientific works published before } 2015 \text { or } \\
\text { after } 2020\end{array}$ \\
Scientific work that focused on the promotion of & $\begin{array}{l}\text { Scientific work not relevant to the scope of } \\
\text { libraries through social media and its uses and } \\
\text { the research topic }\end{array}$ \\
constraints & $\begin{array}{l}\text { Scientific work that was duplicated in the } \\
\text { three databases }\end{array}$ \\
\hline
\end{tabular}

\section{RESULTS AND FINDINGS ANALYSIS}

Three scientific journal databases were used in this study: Google Scholar, Garuda RistekBRIN, and the Directory of Open Access Journal (DOAJ). Searches located 74 results in the databases. Following the previously specified criteria, items were excluded that were duplicated (5 works), not fully accessible (22 works), not relevant to the research focus (19 works), and irrelevant research objects (18 works). Twelve scientific papers were selected for inclusion in the review, consisting of scientific journal articles and theses. The details of the selected scientific papers can be seen in the Appendix.

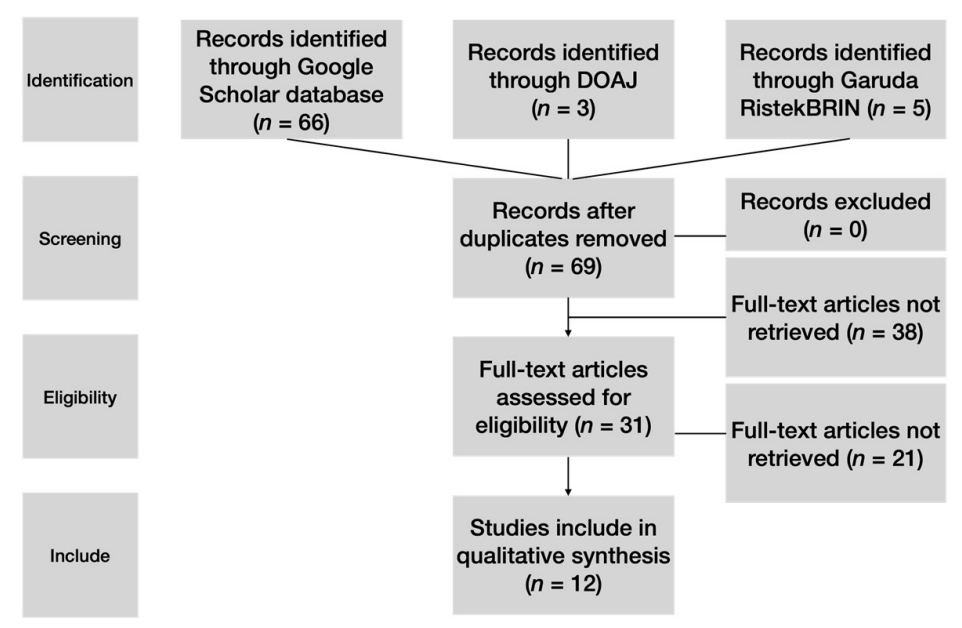

Figure 1. The Work Flow of the Systematic Review

\section{RQ 1: How much research has been done on promoting academic libraries through social media in Indonesia?}

Twelve scientific papers that promoted academic libraries through social media in Indonesia were reviewed (see Appendix for details). The approach used in the research was qualitative. The data 
collection methods of the selected scientific papers included three literature studies and seven case studies (interviews, observations, and documentation).

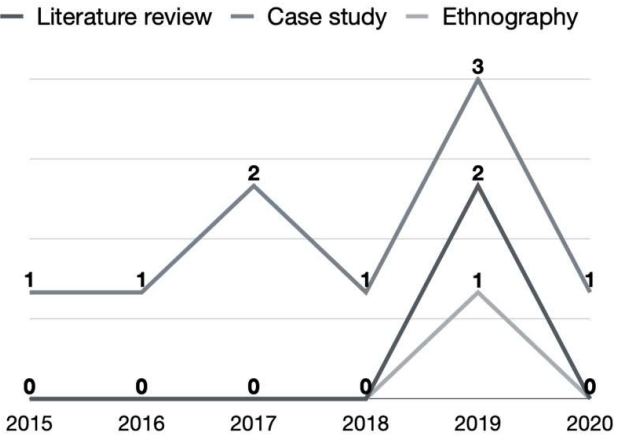

Figure 2. Research Distribution on the Promotion of Academic Libraries through Social Media

The scientific papers used in this research were published from 2015 to 2020 . Figure 2 shows that the number of scientific papers published increased over this period, peaking at six papers in 2019. This year also had the most papers using the case study method (three) and literature study method (two).

In the 2015-2020 period, four scientific papers were published by journals accredited by Sinta 4 and Sinta 5, while the other eight articles were not articles published by journals accredited by Sinta and are considered grey literature. All selected scientific papers researching academic libraries' promotion through social media used qualitative methods, including case studies, interviews, observations, and documentation.

\section{RQ 2: How was social media used as a means of promoting academic libraries in Indonesia?}

The review of the selected scientific papers showed that nine social media categories were used in library promotion. These social media forms include blogs, Facebook (FB), Instagram (IG), Twitter, YouTube, library websites, Line, WhatsApp, and Telegram. Details can be seen in Table 6.

Table 6. Type of Social Media Used for Library Promotion in Selected Studies

\begin{tabular}{|c|c|c|c|c|c|c|c|c|c|c|}
\hline \multirow[t]{2}{*}{ Article } & \multirow[t]{2}{*}{ Location } & \multicolumn{9}{|c|}{ Social Media } \\
\hline & & Blog & FB & IG & Twitter & Youtube & Web & Telegram & WhatsApp & Line \\
\hline ID01 & $\begin{array}{l}\text { Yogyakarta, } \\
\text { Central } \\
\text { Java }\end{array}$ & $\checkmark$ & $\checkmark$ & $\checkmark$ & $\checkmark$ & $\checkmark$ & & & & \\
\hline ID02 & $\begin{array}{l}\text { Yogyakarta, } \\
\text { Central } \\
\text { Java }\end{array}$ & & & $\checkmark$ & & & & & & \\
\hline ID03 & $\begin{array}{l}\text { Yogyakarta, } \\
\text { Central } \\
\text { Java }\end{array}$ & & $\checkmark$ & $\checkmark$ & $\checkmark$ & & $\checkmark$ & & & \\
\hline ID04 & $\begin{array}{l}\text { Surabaya, } \\
\text { East Java }\end{array}$ & & & $\checkmark$ & & & & & & \\
\hline ID05 & $\begin{array}{l}\text { Surakarta, } \\
\text { Central } \\
\text { Java }\end{array}$ & & $\checkmark$ & & & & & & & \\
\hline ID06 & Makassar, & & $\checkmark$ & & & $\checkmark$ & & & & \\
\hline
\end{tabular}




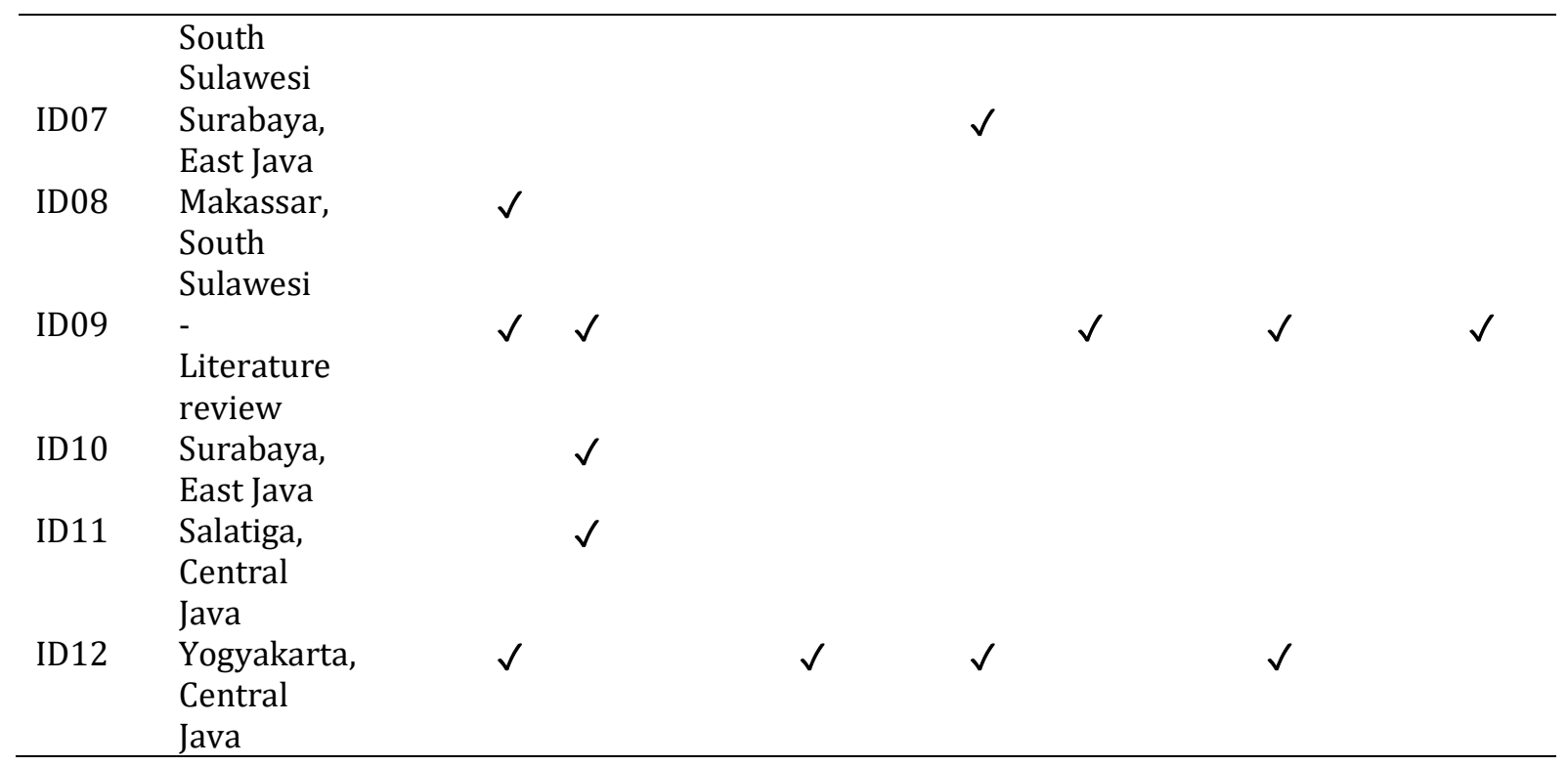

Table 6 shows that five of the twelve selected scientific papers examined more than one form of social media for library promotion (ID01, ID03, ID06, ID09, and ID12). The most widely used social media to promote libraries were Instagram (IG) and Facebook (FB), found in 11 studies (ID01, ID02, ID03, ID04, ID05, ID06, ID08, ID09, ID10, ID11, and ID12). Social media that was rarely used included blogs, Telegram, WhatsApp, and Line. Instagram and Facebook use dominated because the two platforms facilitate the implementation of promotions by allowing librarians or library managers to upload content in the form of photos and videos as well as Live features (e.g., Instagram and Facebook Live). The two platforms also allow for two-way communication between librarians and users.

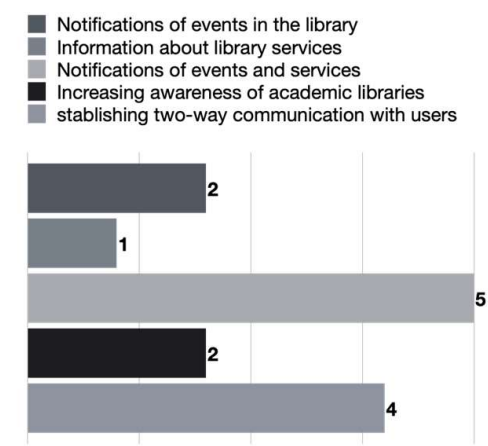

Figure 3. Distribution of Academic Libraries' Promotion Objectives through Social Media in Selected Research

In addition to discussing the use of social media categories and promotional content, these studies discussed library promotion objectives through social media. Researchers divided the use of social media for promotional purposes into five categories: 1) notifications of events in the library, including documentation of library activities; 2) information about library services, including book collections and reviews made by librarians; 3) notifications of events and services; 4) increasing awareness of academic libraries; and 5) establishing two-way communication with users. Based on the results of the review, the majority of academic libraries studied used social media to notify users of events and services. 


\section{RQ 3: What were the obstacles to promoting academic libraries through social media in Indonesia?}

Several categories of obstacles were identified in implementing library promotion through social media. Obstacles included the lack of a specialized staff member to manage promotions and librarians' competence in developing and disseminating social media content. Other obstacles included the adaptation of librarians to use social media, consistency in content creation, minimal user response to promotional activities, and lack of commitment to producing content. Thus, it can be concluded that constraints in the promotion of libraries through social media in Indonesia are comprised of factors internal to libraries.

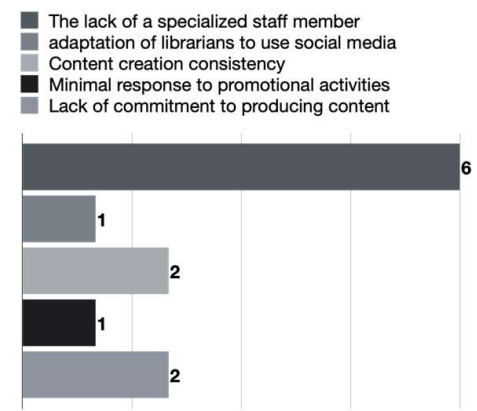

\section{Figure 4. The Distribution of Constraints in the Promotion of Academic Libraries through Social Media in Research}

\section{DISCUSSION}

Library promotion is a step taken to provide information about libraries' products and services to users (Qalyubi, 2007). The promotion is expected to bridge the information gap between libraries and users because promotion itself is part of marketing communication (Syamsuryadi, 2017). Thus, the library's promotion is also expected to notify users of library activities so users have knowledge of libraries' services and can take full advantage of them (Hidayat, 2015).

Based on the scientific papers reviewed in this study, promotions were carried out by academic libraries to disseminate information about events, resources, and services. The activities held were both disseminated and documented through social media. Documentation of activities included user education, book reviews, and religious day celebrations in academic libraries.

Social media is a communication tool that allows interaction between individuals in various media (Amarakoon and Amarakoon, 2012). This description is in line with what is shown by the reviewed research, where interaction between academic libraries and library users was built through photos (documentation) and videos. In addition to documentation, promotional content for academic libraries through social media also focuses on providing information about library services, book reviews, information related to library profiles, and the library's latest book collections to reach users in the online space. These activities mesh with the opinion of Amarakoon and Amarakoon (2012), who state that libraries and information professionals must be actively involved in social networks to be in the same space as users and to attract readers to the library.

Most of the reviewed papers focused on executing academic libraries' promotion through social media without including strategic planning to promote academic libraries. Whereas as a part of marketing, promotion must be planned. For instance, Stueart and Moran (2007) stated that the development of marketing strategies in organisations results from a planning process.

Research on the promotion of libraries through social media using the systematic literature review method is rarely done, either in Indonesia or outside Indonesia. Similar research was 
conducted by Intahchomphoo (2016), but the research focused on an academic library in the field of law (at a law school). In line with Intahchomphoo's (2016) research, social media plays an important role in promoting and marketing services for academic libraries. As Intahchomphoo (2016) found, librarians or library managers often promote information assets owned by libraries such as journals, article and book reviews, reference services, and activities organized by the library.

However, this study had some limitations. The papers reviewed were very diverse, including journal articles, theses, and seminar proceedings. Additionally, the number of similar studies in Indonesia is still limited. Better results might have been produced from a greater number of similar articles, for example, a review of only journal articles.

\section{CONCLUSION}

Promotion by academic libraries is a step taken to disseminate information on the library's products and services. Promotions can inform users of library offerings and activities so that they can take full advantage of services. Based on the literature identified and reviewed in this study, it can be seen that the majority of scientific work that discussed the promotion of academic libraries through social media was published recently, specifically six scientific papers in 2019. The most discussed social media for academic library promotion were Facebook (seven works) and Instagram (seven works). Furthermore, academic libraries in Indonesia that carried out the most promotions through social media were primarily located in Yogyakarta. Finally, obstacles to promoting libraries through social media were primarily located in factors internal to libraries

\section{Acknowledgments}

This work was supported in part by the PUTI Q1 contract NKB-1450/UN2.RST/HKP.05.00/2020, by Kappa Sigma Kappa Indonesia (KSKI), and by Lembaga Pengelola Dana Pendidikan RI (Indonesia Endowment Fund for Education). Any opinions, findings, and conclusions described here are the authors and do not necessarily reflect those of the sponsors

\section{REFERENCES}

A'yunin, N. A. Q. (2018). Promosi Perpustakaan Pusat Studi Sosial Asia Tenggara Universitas Gadjah Mada Yogyakarta Melalui Media Sosial. Libria, 1(1), 48-63.

Allen, L. E., and Taylor, D. M. (2017). The role of the academic Library Information Specialist (LIS) in teaching and learning in the 21st century. Information Discovery and Delivery, 45(1), 1-9. https://doi.org/10.1108/IDD-09-2016-0030

Badan Pusat Statistik. (2019). Survei Sosial Ekonomi Nasional (SUSENAS) 2015-2019. https://www.bps.go.id/site/resultTab

Clark, A., Hostetler, Marna, A., and Loehrlein, K. (2014). A New Team, A New Vision: One Library's Adventures in Outreach. Indiana Libraries, 33(2), 19-23.

Collins, G., and Quan-Haase, A. (2014). Are Social Media Ubiquitous in Academic Libraries? A Longitudinal Study of Adoption and Usage Patterns. Journal of Web Librarianship, 8(1), 4868. https://doi.org/10.1080/19322909.2014.873663

Darmono. (2007). Perpustakaan Sekolah: Pendekatan Aspek Manajemen dan Tata Kerja. Grasindo.

Globe, J. (2020). Indonesia Has 197 Million Internet Users in 2020, APJII Survey Shows. https://jakartaglobe.id/tech/indonesia-has-197-million-internet-users-in-2020-apjiisurvey-shows

Handayani, P. W. (2017). Systematic Review dengan PRISMA (Preferred Reporting Items for Systematic Reviews and Meta-Analyses. Makalah Workshop Riset Sistem Informasi Fakultas Ilmu Komputer UI, 1-3 Agustus. https://dosen.perbanas.id/wpcontent/uploads/2017/08/Sesi2-SYSTEMATIC-REVIEW-DENGAN-PRISMA.pdf

Hanley, Terry and Cutts, L. (2013). What is a systematic review. Counselling Psychology Review, 28(4), https://www.researchgate.net/publication/259592128_What_is_a_systematic_review 
Hidayat, N. (2015). Strategi Promosi Layanan Perpustakaan Utsman Bin Affan Universitas Muslim Indonesia Makassar. UIN Alauddin.

Indonesia. (2019). Keputusan Menteri Ketenagakerjaan Republik Indonesia Nomor 236 Tahun 2019 tentang penetapan Standar Kompetensi Kerja Nasional Indonesia kategori kesenian, hiburan dan rekreasi golongan popo perpustakaan, arsip, museum dan kegiatan kebudayaan lainnya. https://pusdiklat.perpusnas.go.id/regulasi/download/12

Indonesia, Perpustakaan Nasional. (2007) Undang-Undang Nomor 43 tahun 2007 tentang Perpustakaan, Pub. L. No. 43. https://library.usu.ac.id/wp-content/uploads/2019/12/UUNomor-43-Tahun-2007-Tentang-Perpustakaan.pdf

Islamy, M. A. N., and Laksmiwati, I. (2020). Pemanfaatan Media Sosial Sebagai Sarana Promosi Layanan Perpustakaan Institut Seni Indonesia Surakarta. Nusantara - Journal of $\begin{array}{llll}\text { Information and } \quad \text { Library } & \text { Studies, } & 3(1), & \end{array}$ http://ojs.uninus.ac.id/index.php/JILS/article/view/804/589

Kitchenham, B. (2004). Procedures for Performing Systematic Reviews. Keele University.

Mardiastuti, A., Suciati, U., dan W. (2019). Pemanfaatan Media Viral Untuk Memasarkan Produk dan Layanan Perpustakaan Universitas Gadjah Mada Menghadapi Era Industri 4.0. Media Pustakawan, 26(3), 233-244. https://ejournal.perpusnas.go.id/mp/article/view/546

Miyata, N. S. (2019). Efektivitas Penggunaan Instagram Sebagai Media Promosi Perpustakaan Universitas Kristen Petra. Agora, http://publication.petra.ac.id/index.php/manajemen-bisnis/article/view/9571/8642

Patil, S.K., A., and Pradhan, P. (2014). Library Promotion Practices and Marketing of Library Services: A Role of Library Professionals. Procedia - Social and Behavioral Sciences, 133, 249-254. https://doi.org/10.1016/j.sbspro.2014.04.191

Petticrew, Mark dan Roberts, H. (2006). Systematic Reviews in the Social Sciences: A Practical Guide. Blackwell Publishing.

Prabowo, A., and Absor, U. (2019). Mediatisasi Perpustakaan Perguruan Tinggi Di Yogyakarta Pada Instagram Dalam Promosi Kepada Masyarakat. Journal of Information and Library Studies, 2(2), 171-188 [Online] terdapat di: http://ojs.uninus.ac.id/index.php/JILS/article/view/722/474 [diakses pada 03 Agustus 2021]

Prabowo, O. R. and F. W. (2017). Instagram Sebagai Media Promosi dan Interaksi Perpustakaan UIN Sunan Kalijaga. Prosiding Seminar Nasional Dan Call For Papers Prodi Ilmu Perpustakaan $U M$.

Puspohadi, U. (2016). Promosi Jasa Layanan Perpustakaan : Studi Kasus di Perpustakaan Universitas Kristen Petra Surabaya. UIN Sunan Kalijaga.

Qalyubi, Syihabuddin, et. al. (2007). Dasar-dasar Ilmu Perpustakaan dan Informasi. Jurusan Ilmu Perpustakaan dan Informasi Fakultas Adab UIN Sunan Kalijaga.

Sudiar, N., Fiqru Mafar, A., and Rosman. (2017). Model Promosi Perpustakaan Perguruan Tinggi di Pekanbaru. Lentera Pustaka, 3(1), 19-25.

Suharso, P., and Pramesti, A. N. (2020). Promosi Perpustakaan Melalui Instagram: Studi di Perpustakaan Universitas Airlangga. Publication Library and Information Science, 3(2), 6674. https://doi.org/10.24269/pls.v3i2.2074

Syamsuryadi. (2017). Strategi Pustakawan Mempromosikan Perpustakaan Universitas Fajar Makassar [UIN Alauddin]. http://repositori.uin-alauddin.ac.id/2563/1/Syamsuryadi.pdf

Torres-Carrion, P.V., Aciar, S., Gonzalez-Gonzalez, C.S., and Rodriguez-Moralex, G. (2018). Methodology for Systematic Literature Review applied to Engineering and Education. IEEE Global Engineering Education Conference (EDUCON), 1364-1373.

Utomo, R. E. P. (2019). Pemanfaatan Sosial Media Sebagai Bentuk Inovasi, Strategi Komunikasi dan Kreatifitas Layanan di Perpustakaan Perguruan Tinggi. 3(1). http://journal.iaincurup.ac.id/index.php/TI/article/view/627/576

Wiji, S. (2018). Attitudes and roles of librarians in the modern era (an ethical and cultural approach). International Journal of Library and Information Science, 10(4), 41-44. https://doi.org/https://doi.org/10.5897/ IJLIS2016.0667

Wulandari, E. ., Rizal, Edwin, A., and E., L. (2020). STRATEGI PROMOSI E-JOURNAL UNTUK 
GENERASI-Z DI PERPUSTAKAAN UNIVERSITAS PADJADJARAN. Khizanah Al-Hikmah: Jurnal Ilmu Perpustakaan, Informasi, Dan Kearsipan, 8(1), 11-20. https://doi.org/10.24252/kah.v8i1a1

Yenianti, I. (2019). Promosi Perpustakaan Melalui Media Sosial Di Perpustakaan IAIN Salatiga. Pustabiblia: Journal of Library and Information Science, 3(2), 223-237. https://doi.org/10.18326/pustabiblia.v3i2.223-237 